\title{
Length-Weight Relationships and Growth Patterns of Local Fishes of the Medium Perennial Vavuniya Reservoir, Sri Lanka
}

\author{
A.E.S. Patrick ${ }^{1, *}$, S. Kuganathan ${ }^{2}$ and U. Edirisinghe ${ }^{3}$ \\ ${ }^{1}$ Department of Bio-Science, Faculty of Applied Science, Vavuniya Campus of the \\ University of Jaffna, Sri Lanka \\ ${ }^{2}$ Department of Fisheries, Faculty of Science, University of Jaffna, Sri Lanka \\ ${ }^{3}$ Postgraduate Institute of Agriculture, University of Peradeniya, Sri Lanka
}

\begin{abstract}
A B S T R A C T
Linear regression analysis of length-weight relationships (LWRs) were studied to reveal the growth patterns of 380 specimens belonging to 10 species, 9 genera and 5 families of local fish in Vavuniya reservoir, Sri Lanka during January, 2013 to August, 2014. The regression coefficient value ' $b$ ' from LWR and statistical comparison from the ideal value $(b=3)$ were used to find the growth patterns. Most of the local species showed isometric growth except Amblypharyngodon melettinus, Puntius sarana and Heteropneustes fossilis. Only Channa striata $(b=2.996, \mathrm{p}=0.396)$ and females of Puntius dorsalis $(b=$ $3.076, \mathrm{p}=0.234$ ) appeared in the catch throughout the study period and showed a strong correlation between length and weight. Combined sexes of, Glossogobius giuris $(b=3.178, \mathrm{p}=0.216)$, Labeo dussumieri $(b=$ 2.752, $\mathrm{p}=0.069)$ and females of Mystus keletius $(b=2.823, \mathrm{p}=0.078)$ showed isometric growth. However, positive allometric growth for $P$. sarana females $(b=3.182, \mathrm{p}=0.000)$ and negative allometric growth for combined sexes of $H$. fossilis $(b=2.613, \mathrm{p}=0.001)$ were observed. During the drought period (July to August, 2014), A. melettinus, Esomus thermoicos (endemic) and Rasbora daniconius were observed at the sluice. E. thermoicos $(b=3.163, \mathrm{p}=0.181)$ and $R$. daniconius $(b=3.065, \mathrm{p}=0.393)$ obeyed the cubic law and showed an isometric growth pattern. However, A. melettinus showed a negative allometric growth $(b=2.367, \mathrm{p}=0.002)$. Although, most of the local fish indicated isometric growth that reflected successful thriving, allometric growth reflected the sensitivity for environmental and habitat characteristics. Therefore, this study revealed the baseline evidence on the LWRs and the growth patterns, which could be considered for studying the survival of local fish to reach the optimal species richness and abundance.
\end{abstract}

Article Information
Received 06 November 2018
Revised 11 May 2019
Accepted 24 June 2019
Available online 14 May 2021
Authors' Contribution
AESP was responsible for data
collection, designing, analyzing and
writing the manuscript. SK guided in
the statistical analyzing. SK and UE
were involved in overall guidance and
correction of the manuscript.
Key words
Length-weight relationship, Growth
pattern, Local fish.

Received 06 November 2018

Accepted 24 June 2019

Authors' Contribution

AESP was responsible for data

collection, designing, analyzing and

were involved in overall guidance and

of the manuscript.

pattern, Local fish.

\section{INTRODUCTION}

$\mathrm{R}_{\mathrm{s}}$ eservoir cascade systems in Vavuniya district, Sri Lanka, provide habitats for freshwater fish species that play an important role in inland fisheries. Vavuniya reservoir is one of the tropical low land reservoirs in this cascade system and has been experiencing significant decrease in fish species composition and abundance. These losses could have been happened mainly due to extreme hydroclimatic events (especially drought), irrational fishing, irrigation and pollution impacts (Patrick et al., 2017). Therefore, fisheries management should be implemented with rational understanding of fish biology and hence the ecology of local fish species is mandatory. However, there was a dearth in basic data with respect to fish biology of local fish in Vavuniya district due to lack of research.

Among the fish biology studies, length-weight relationship (LWR) of fish is an important fisheries

\footnotetext{
Corresponding author: aespatrick@vau.jfn.ac.lk 0030-9923/2021/0004-1291 \$ 9.00/0

Copyright 2021 Zoological Society of Pakistan
}

management tool, because they allow the estimation of the average weight of the fish of a given length group by establishing a mathematical relationship between length and weight (Beyer, 1987). According to Le Cren (1951), knowledge of the LWR of a fish is essential, since various important biological aspects, viz., general wellbeing of fish, appearance at first maturity, onset of spawning, etc., can be assessed with the help of condition factor, a derivative of this relationship.

Estimated ' $b$ ' value from Length-weight relationship analysis and statistical comparison of it with the ideal regression coefficient value $(b=3)$ are widely used to monitor the growth patterns of fish species. Statistically, if the regression coefficient value did not significantly differ ( $p>0.05$ ) from the ideal value 3 , that obeyed the cubic law, which ultimately resulted in isometric growth of fish.

Although, most European and North American freshwater fishes had their regression data of LWR, it is missing for most tropical fish (Zaret, 1980; Kilambi, 1986; De Silva, 1991). Muhammad et al. (2017) had stated that very poor and scanty information regarding the LWR of freshwater catfishes were available in Pakistan. 
Thus, it justifies the need for the estimation of LWR of tropical fish for the ecological and conservation values. As these fish are integral trophic components of aquatic food web, LWR play an important role to monitor the status of local fish in this reservoir. Present study provides LWR data of ten fish species including four species that do not have any information regarding the LWR even in Fish Base (Froese and Pauly, 2018), viz., Amblypharyngodon melettinus, Esomus thermoicos, Labeo dussumieri and Mystus keletius.

\section{MATERIALS AND METHODS}

Site selection and specimen collection

Vavuniya reservoir $\left(8^{\circ} 45^{\prime} 13.75-59.23^{\prime \prime} \mathrm{N} ; 80^{\circ}\right.$ $30^{\prime} 7.50$ - 53.21” E), a medium perennial water body, situated near the densely populated urban area of Vavuniya City, Sri Lanka. Freshly captured fish species (gill net's stretched mesh sizes; 3", 31/2", 33/4", 4", 41/2", 43/4" and occasionally line and pole) were randomly collected from the landing sites from January, 2013 to August, 2014. Additional collections of small sized species were also done (by using mosquito nets) at the sluice, spills and outlets during extreme hydro-climatic periods (drought and floods). Specimens were transferred to the Environmental Bio-Laboratory, Vavuniya Campus of the University of Jaffna. Species identification was done, using standard taxonomic keys and external morphological descriptions (Munro, 1955; Pethiyagoda, 1991; Goonatilakea, 2012).

\section{Determination of length-weight relationship}

Early juveniles, very old specimens and unsexed were removed (Froese, 2006). Total body weight (W) of each fish of different species was measured to the nearest
$0.01 \mathrm{~g}$ by an electronic balance (Precisa XB $320 \mathrm{C}$ ). The distance from the tip of the mouth to the end of the caudal fin (total length) was measured to the nearest $0.1 \mathrm{~cm}$ using a fish measuring board. Sexing was done by analysis of the gonads. Total length (TL) and corresponding total body weight (W) of fish species were used to determine the length-weight relationship by using the following equation (Le Cren, 1951 and Ricker, 1973):

$$
\mathrm{W}=\mathrm{a} \mathrm{L}^{\mathrm{b}}
$$

Logarithmic transformation of the LWR was done by using the above equation to determine the linear regression analysis and scatter diagrams of length and weight were plotted and the outliers were excluded (Froese et al., 2011).

$$
\log \mathrm{W}=\log \mathrm{a}+\mathrm{b} \log \mathrm{TL}
$$

\section{Statistical analysis of data}

In LWR linear regression analysis, the slope of regression lines explicit the regression coefficient value ' $b$ ' (slope of LWR). Significant variation in the estimates of ' $b$ ' for the fish species was examined from the expected value (ideal value ' $b$ ' $=3$ ) and was tested by t-test (Snedecor, 1963: Jayaprakash, 2001). Students't-test was employed by dividing the difference between ' $b$ ' and ' 3 ' by standard error of ' $b$ ' (Zar, 1996).

\section{RESULTS AND DISCUSSION}

Total of 380 specimens of 10 fish species belonging to five families were identified and studied for LWR and growth patterns. Those 10 fish species were Amblypharyngodon melettinus (Valenciennes, 1844), Channa striata (Bloch, 1793), Esomus thermoicos (Endemic) (Valenciennes, 1842), Glossogobius giuris (Hamilton, 1822), Heteropneustes fossilis (Bloch, 1794),

Table I.- Statistical summary of length-weight relationships and growth patterns of local fish species in Vavuniya

\begin{tabular}{|c|c|c|c|c|c|c|c|c|c|c|c|}
\hline \multirow[t]{2}{*}{ Family } & \multirow[t]{2}{*}{ Species } & \multirow[t]{2}{*}{ Sex } & \multicolumn{3}{|c|}{ Total length (cm) } & \multirow{2}{*}{$\begin{array}{l}\text { Max. known } \\
\text { length (cm) }\end{array}$} & \multicolumn{2}{|c|}{ Regression parameters } & \multirow[t]{2}{*}{ p value } & \multirow[t]{2}{*}{$r^{2}$} & \multirow[t]{2}{*}{ SE (b) } \\
\hline & & & $n$ & Min & Max & & $a$ & $b$ & & & \\
\hline Channidae & C. striata & $\mathrm{C}$ & 42 & 22.7 & 50.1 & 61.0 & 1.854 & 2.996 & 0.396 & 0.98 & 0.0633 \\
\hline \multirow[t]{6}{*}{ Cyprinidae } & P. dorsalis & $\mathrm{F}$ & 70 & 12.0 & 20.2 & 25.0 & 1.682 & 3.076 & 0.234 & 0.96 & 0.0742 \\
\hline & P. sarana & $\mathrm{F}$ & 99 & 07.2 & 26.5 & 42.0 & 1.729 & 3.182 & 0.000 & 0.99 & 0.0346 \\
\hline & L. dussumieri & $\mathrm{C}$ & 30 & 22.5 & 33.0 & 50.0 & 1.302 & 2.752 & 0.069 & 0.94 & 0.1309 \\
\hline & E. thermoicos & $\mathrm{C}$ & 19 & 04.5 & 09.9 & 12.7 & 2.021 & 3.163 & 0.181 & 0.97 & 0.1321 \\
\hline & A. melettinus & $\mathrm{C}$ & 29 & 06.0 & 10.5 & 08.0 & 1.271 & 2.367 & 0.002 & 0.87 & 0.1760 \\
\hline & R. daniconius & $\mathrm{C}$ & 28 & 05.7 & 10.8 & 15.0 & 1.951 & 3.065 & 0.393 & 0.94 & 0.1525 \\
\hline Heteropneustidae & H. fossilis & $\mathrm{C}$ & 21 & 18.3 & 30.4 & 31.0 & 1.566 & 2.613 & 0.001 & 0.97 & 0.1000 \\
\hline Gobiidae & G. giuris & $\mathrm{C}$ & 21 & 16.4 & 39.0 & 50.0 & 2.003 & 3.178 & 0.216 & 0.95 & 0.1641 \\
\hline Bagridae & M. keletius & $\mathrm{F}$ & 21 & 10.3 & 24.1 & 18.0 & 1.517 & 2.823 & 0.078 & 0.98 & 0.0966 \\
\hline
\end{tabular}
reservoir, Sri Lanka.

$\mathrm{C}$, combined sexes; F, females; $\mathrm{n}$, sample size; Min, minimum; Max, maximum; $a$, intercept; $b$, regression coefficient; SE $(b)$, standard error of ' $b$ '; $r^{2}$, coefficient of determination; $p$, probability test value. 
Labeo dussumieri (Valenciennes, 1842), Mystus keletius (Valenciennes, 1840), Puntius dorsalis (Jerdon, 1849), Puntius sarana (Hamilton, 1822) and Rasbora daniconius (Hamilton, 1822).

Sample size, sex, minimum TL, maximum TL and maximum reported length (standard or total length) for every species along with LWR, coefficient of determination $\left(r^{2}\right)$, intercept ' $a$ ', regression coefficient ' $b$ ', standard error of ' $b$ ' (SE $b)$ and probability test value ' $p$ ' (significant deviation from ideal $b$ value 3 ) were presented in Table I. Findings of this study indicated that most of the indigenous species in Vavuniya reservoir showed a strong correlation between length and weight relationships. In nine out of the 10 species, the coefficient of determination $\left(r^{2}\right)$ values were higher than 0.94 except in one species (A. melettinus) that showed $r^{2}=0.87$ (Table I). Isometric growth patterns were observed in most of the species except three species viz., A. melettinus, $P$. sarana and $H$. fossilis. This was justified by insignificant variations $(p>0.05)$ between ideal ' $b$ ' value $=3$ from the estimates of ' $b$ '. For most of the species, the estimated ' $b$ ' values ranged between 2.752 and 3.178 .

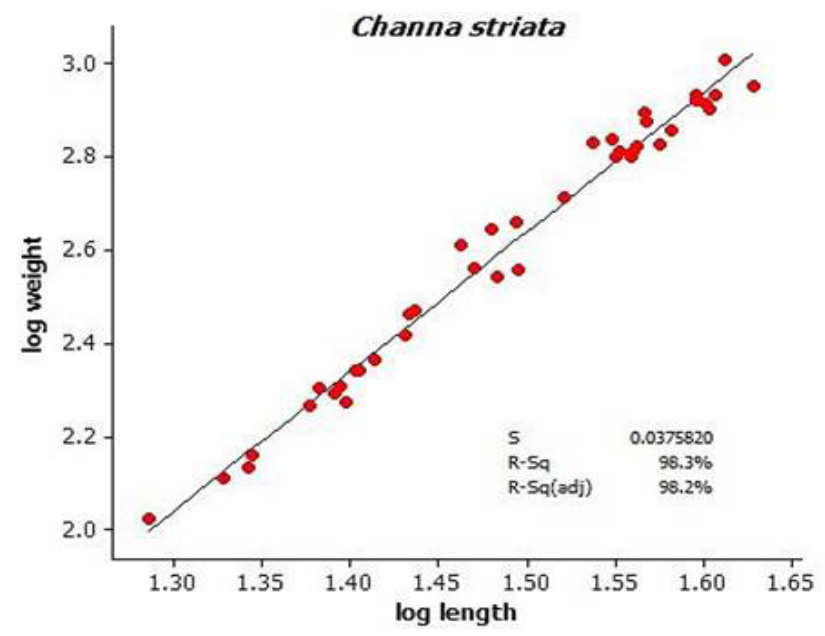

Fig. 1. Length-weight relationship of Channa striata (combined sex).

Fish species exhibiting isometric growth patterns

There were $70 \%$ of the fish species showed isometric growth pattern. Among these species Channa striata and Puntius dorsalis were the indigenous species available in the catch throughout the research period. Estimates of regression coefficient value ' $b$ ' $(b=2.99)$ did not differ significantly $(p=0.396)$ from the ideal ' $b$ ' value $=3$ among both sexes of $C$. striata (Table I). Hence, $C$. striata followed the cubic law and its growth was proportionally three-dimensional, representing isometric growth pattern with strong $\left(r^{2}=0.98\right)$ LWR relationship (Fig. 1). Ali et al. (2013) reported LWR of $C$. striata as $b=2.73$ and $r^{2}=0.61$, which was not significantly different from the cubic value indicating that the species showed an isometric growth pattern in Lake Vembanad, Kerala, India. This was similar to the growth pattern observed in Vavuniya reservoir, Sri Lanka as well. However, stronger $b$ and $r^{2}$ values were shown in this study than Kerala.

Interestingly, only females of Puntius dorsalis appeared in the catch in all the instances (from January, 2013 to July, 2014) and showed a strong coefficient of determination $\left(r^{2}=0.96\right)$ between length and weight. The regression coefficient $b$ (slope of Fig. 2) was obtained as 3.076 and statistically did not show a significant deviation $(p=0.234)$ and was not far from the ideal value 3 , which justified the isometric growth for $P$. dorsalis. Therefore, $P$. dorsalis (females), revealed neither robustness nor slender growth patterns in Vauvniya reservoir. Similarly, P. dorsalis from Cholavaram Lake in Chennai, India, had a ' $b$ ' value $=3.082$ and $r^{2}=0.991$, which showed statistically strong isometric growth (Thirunavukkarasu et al., 2012). Various studies on the LWR obtained for $P$. dorsalis were similar to this study. Findings from Hile (1936) and Martin (1949) showed that the value of ' $b$ ' usually ranged between 2.5 to 4.0 . Therefore, female $P$. dorsalis could be expected to thrive successfully in Vavuniya reservoir. However, information regarding the males in the catch was not available, which justify the need for future research. According to the data obtained in this study, Vavuniya reservoir seems to be an ideal habitat for the growth of $C$. striata and $P$. dorsalis.

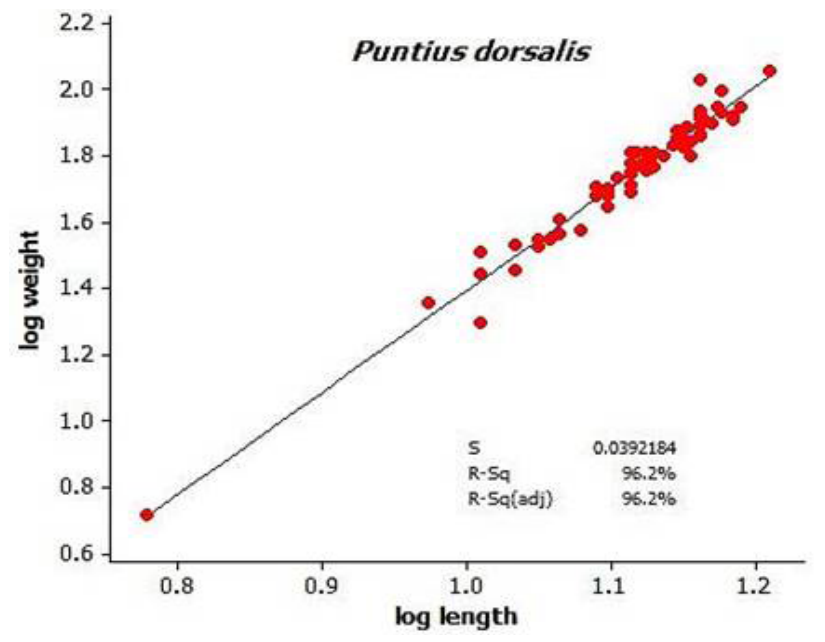

Fig. 2. Length-weight relationship of Puntius dorsalis (females). 
Some species such as Glossogobius giuris, Labeo dussumieri and Mystus keletius did not appear during all months of the study period. Peak catches of these species were found only in a few months and moderate catches were in some other months. In G. giuris, LWR (Fig. 3) was strong $\left(r^{2}=0.95\right)$ and estimated ' $b$ ' values for male, female and combined sex coincided with the ideal value 3 statistically ( $p=0.216)$. These results indicated that G. guiris showed isometric pattern of growth. Hence, in Vavuniya reservoir G. giuris (both males and females) showed ideal growth pattern. According to Islam and Mollah (2013), LWR for male and female of $G$. giuris revealed that ' $b$ ' values as 2.887 and 3.291, respectively in Kaila Beel, Bangladesh. In Atrai River in northern Bangladesh, LWR of G. giuris showed ' $b$ ' for males as 2.768 and females as 2.667, which were statistically different from the ideal value and disagreed with cubic law (Joadder, 2009). Variations in ' $b$ ' can be justified by several factors such as sex, gonad maturity, sampling periods, preservative methods and environmental conditions (Tesch, 1971). However, using fresh specimens of $G$. guiris during the entire two-year study period in Vavuniya reservoir reflected isometric growth, which justified habitat suitability.

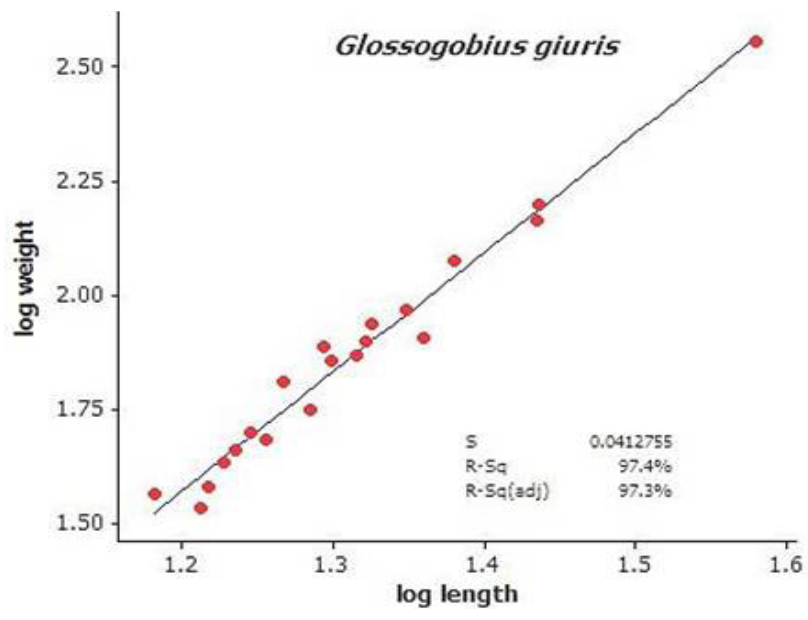

Fig. 3. Length-weight relationship of Glossogobius giuris (combined sex).

Length-weight relationships of Labeo dussumieri (Fig. 4) for combined sex were strong $\left(r^{2}=0.95\right)$ and the ' $b$ ' values of $L$. dussumieri obtained as 2.752 , which was statistically $(p=0.069)$ equal to cubic value. Smith (1991) has also reported that the ' $b$ ' value of $L$. dussumieri as 2.8 in lowland region of Mahaweli Ganga, Sri Lanka. Although this region experienced the same bimodal pattern of rainfall as in Vavuniya reservoir $(b=2.75)$, Mahaweli Ganga is a riverine habitat, which receives highland discharges. Therefore, slight variations in the ' $b$ ' values can be expected.

In this study, ' $b$ ' value of Mystus keletius female was 2.823. It was obtained from $\operatorname{LWR}\left(r^{2}=0.98\right)$ and statistically $(p=0.078)$ did not deviate from isometric value (Fig. 5). In Bangladesh, the overall coefficient value ' $b$ ' $=3.058$ for Mystus sp., which was obtained from LWR was close to the isometric value (Hossain et al., 2006). Suggestively, Vavuniya reservoir provided a hospitable environment for female $M$. keletius as indicated by the corresponding ideal growth. However, further research is needed to incorporate both sexes with broader sample size ranges.

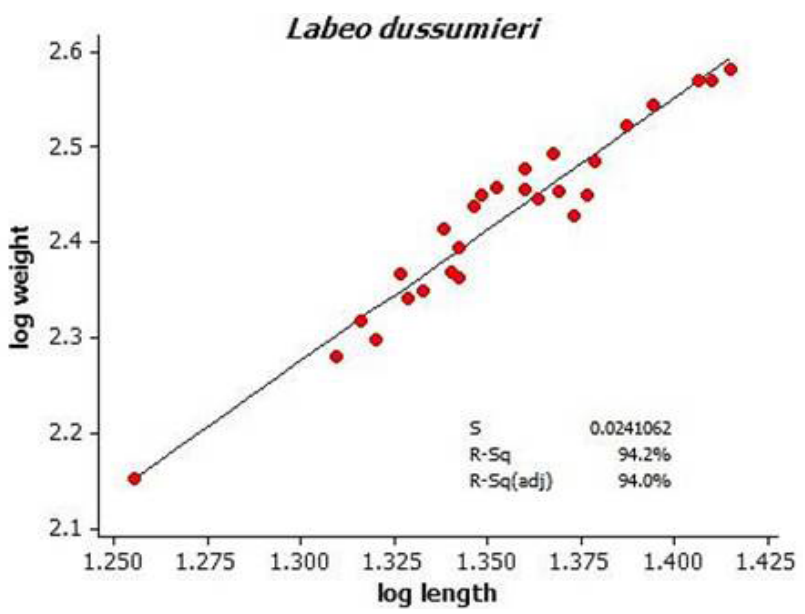

Fig. 4. Length-weight relationship of Labeo dussumieri (combined sex).

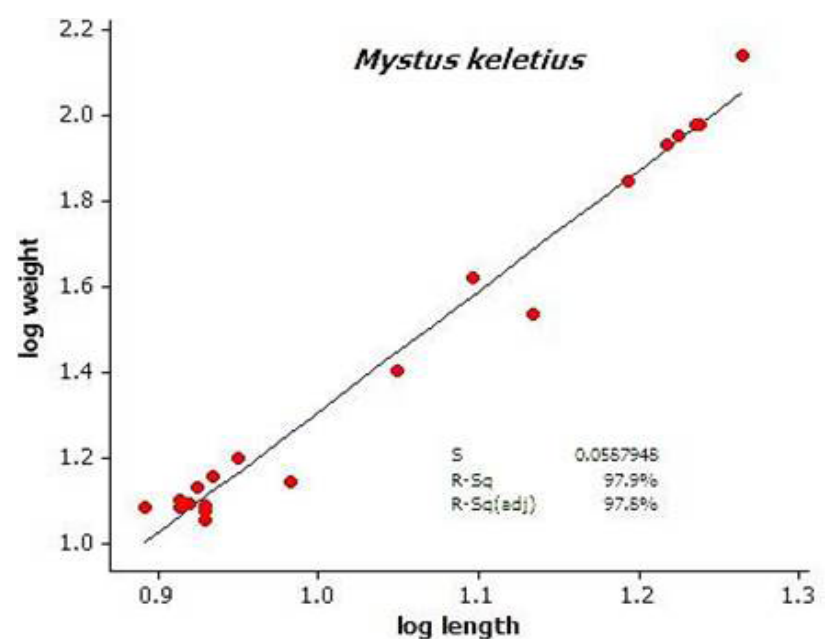

Fig. 5. Length-weight relationship of Mystus keletius (females).

Usually, some of the small-sized species did not appear in the catch. However, extreme weather events such as flooding and drought facilitated their availability 
on rare occasions. Among the small-sized species Esomus thermoicos was an endemic freshwater fish species of Sri Lanka that showed an isometric growth pattern. Here, the estimated ' $b$ ' value was 3.163 , which obeyed the cubic law statistically $(p=0.181)$ and showed strong $r^{2}$ which is 0.97 (Fig. 6). Interestingly, E. thermoicos could survive in the hot wells in Trincomalee, Sri Lanka where this species can tolerate $40^{\circ} \mathrm{C}$ successfully (Pethiyagoda, 1991). Consequently, E. thermoicos adapted well even during drought period and showed isometric $(b=3.16$ and $p=0.181$ ) growth pattern in Vavuniya reservoir, Sri Lanka.

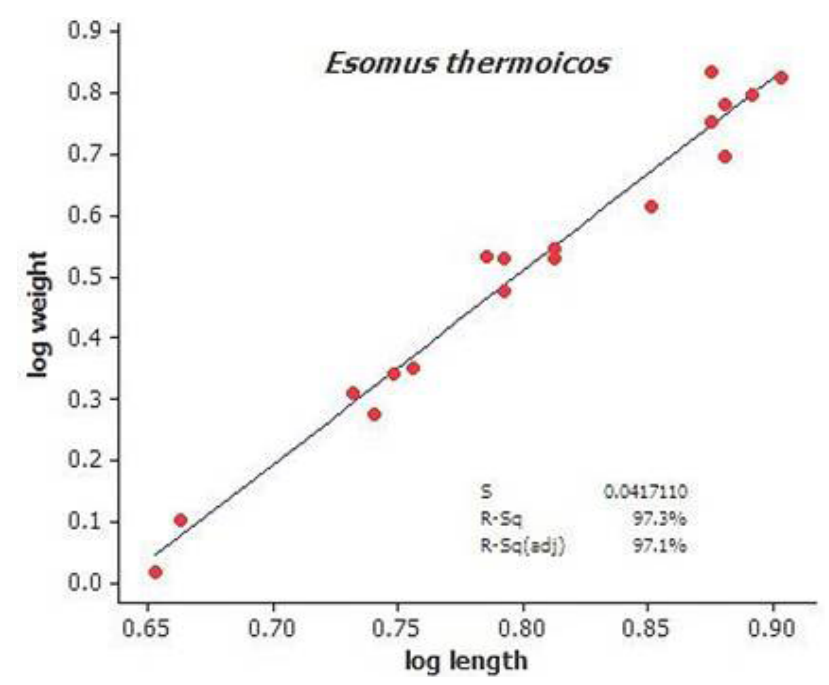

Fig. 6. Length-weight relationship of Esomus thermoicos (combined sex).

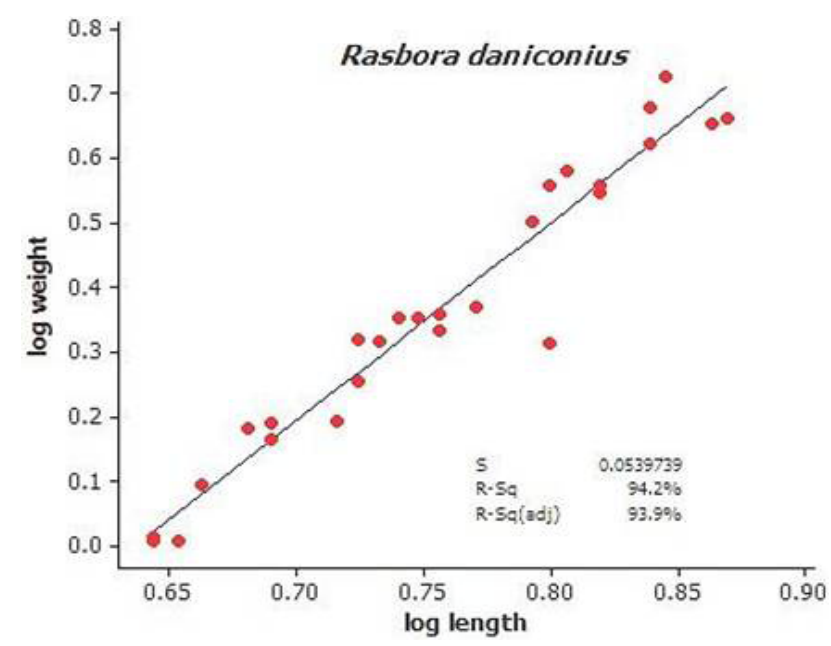

Fig. 7. Length-weight relationship of Rasbora daniconius (combined sex).

The estimated ' $b$ ' value for Rasbora danicnius was 3.065 , corresponding statistically $(p=0.393)$ with the cubic law. LWR linear regression analysis revealed strong coefficient of determination $r^{2}=0.94$ (Fig. 7). However, Rasbora daniconius from Achancoil River, Kerala, India showed a negative allometric growth for both adults $\left(b=2.641\right.$ and $\left.r^{2}=0.97\right)$ and juveniles $\left(b=2.613\right.$ and $r^{2}=$ 0.97) (Sunil, 2000). Therefore, $R$. daniconius showed an isometric growth pattern in Vavuniya reservoir and seem to be thriving during drought periods.

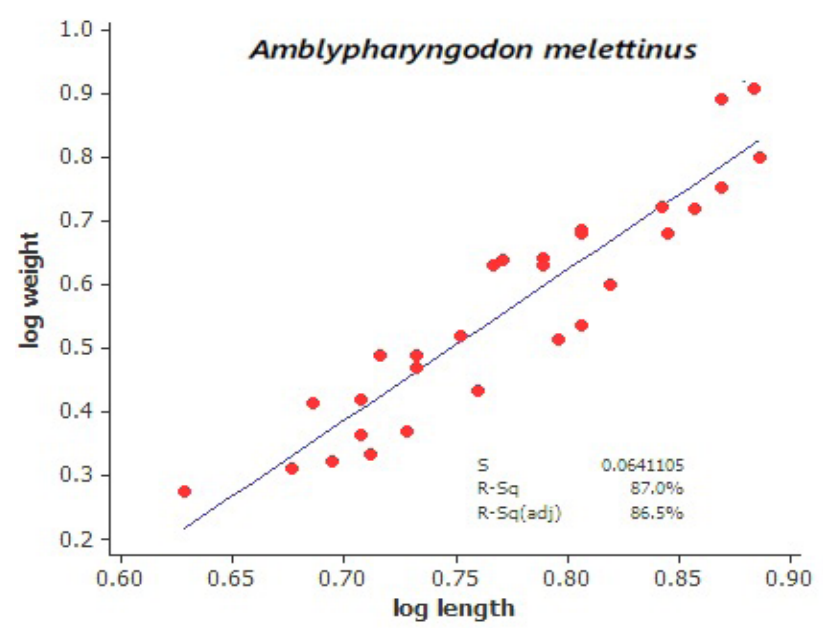

Fig. 8. Length-weight relationship of Amblypharyngodon melettinus (combined sex).

Fish species exhibiting allometric growth patterns

Interestingly, allometric growth pattern was observed only in three species viz., Amblypharyngodon melettinus, Heteropneustes fossilis and Puntius sarana. Among these species $H$. fossilis and $P$. sarana were available in the catch during most of the months. However, $A$. melettinus was collected only during the drought period (July and August 2014) at the sluice. Lower coefficient of determination $\left(r^{2}\right)=0.87$ was observed in A. melettinus compared to all other species examined. A. melettinus showed a negative allometric $(b=2.367)$ growth that indicated significant variation $(p=0.002)$ from the isometric regression coefficient value ' $b$ ' $=3$. According to the LWR equation (Fig. 8), increase in body weight was much lower than the increase in length of the fish. Alam et al. (2013), found that Amblypharyngodon sp. showed a positive allometric growth pattern, where the ' $b$ ' value was 3.03 in Nawabganj reservoir, Bangladesh. In comparison to Nawabganj reservoir, this species showed a negative allometric growth pattern $(b=2.367$ and $p=$ 0.002 ) in Vavuniya reservoir, during drought period (July and August, 2014). This indicated that $A$. melettinus did not adapt well in Vavuniya reservoir. This may be due to the scarcity of feeds and its feeding habits. According to 
Pethiyagoda (1991) A. melettinus is not greedy to consume formulated diets and only accept finely ground cereals or phytoplankton in the mid water of the aquarium and starve at night and filter during day (Schiemer, 1996) especially, seston-filtering (Silva et al., 2008). Hence, slender growth can be attributed towards its feeding habits.

In Vavuniya reservoir, $H$. fossilis showed a significant variation $(p=0.001)$ from the isometric regression coefficient value $' b$ ' $=3$ (Table I). Indeed, there was a strong coefficient of determination $r^{2}=0.97$ derived from LWR graph (Fig. 9) revealing the negative allometric $(b=2.613)$ growth. These findings indicate that the increase in body weight was much lower than the increase in length of the fish. In this study gut analysis of $H$. fossilis did not show a prominent fullness of gut with feeds. However, in February, 2013 the gut analysis of $H$. fossilis showed a lot of gastropods (molluscs) and maturing ovaries. During this period the rainfall and the water level were as high as 264.4 $\mathrm{mm}$ and $398.1 \mathrm{~cm}$, respectively (Patrick et al., 2017).

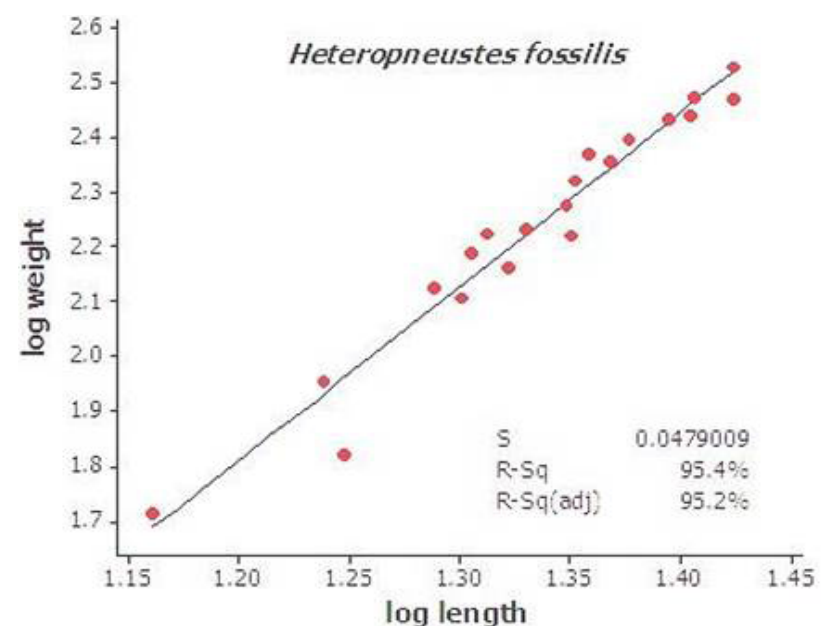

Fig. 9. Length-weight relationship of Heteropneustes fossilis (combined sex).

Muhammad et al. (2017) observed a negative allometric growth $(b=2.13)$ and coefficient of determination $\left(r^{2}=0.92\right)$ for Heteropneustes fossilis in Indus River, Pakistan. Similarly, in India, Deepar Beel, a Ramsar site of Assam also showed a negative allometric growth for males $(b=1.27)$ and females $(b=2.71)$ (Das et al., 2015). This finding was very supportive for $H$. fossilis in Vavuniya reservoir, where it also showed a negative allometric growth for combined sexes, indicating a significant deviation $(p=0.001)$ from the isometric regression coefficient value ' $b$ ' $=3$. The negative allometric growth performance of $H$. fossilis can be attributed to lower feed intake or reproduction or unfavourable environmental factors (Das et al., 2015; Pathak, 1975; Javaid, 1971). In Vavuniya reservoir, gut analysis of $H$. fossilis did not show a prominent consumption of a specific feed. However, during peak water level and rainfall periods, this species had ingested a significant number of gastropod molluscs. Also, Narejo et al. (2016) had reported that this species showed empty stomach, $1 / 4$, and $1 / 2$ filled and more feed preferences towards crustaceans in Manchar Lake, Jamshoro Sindh district, Pakistan.

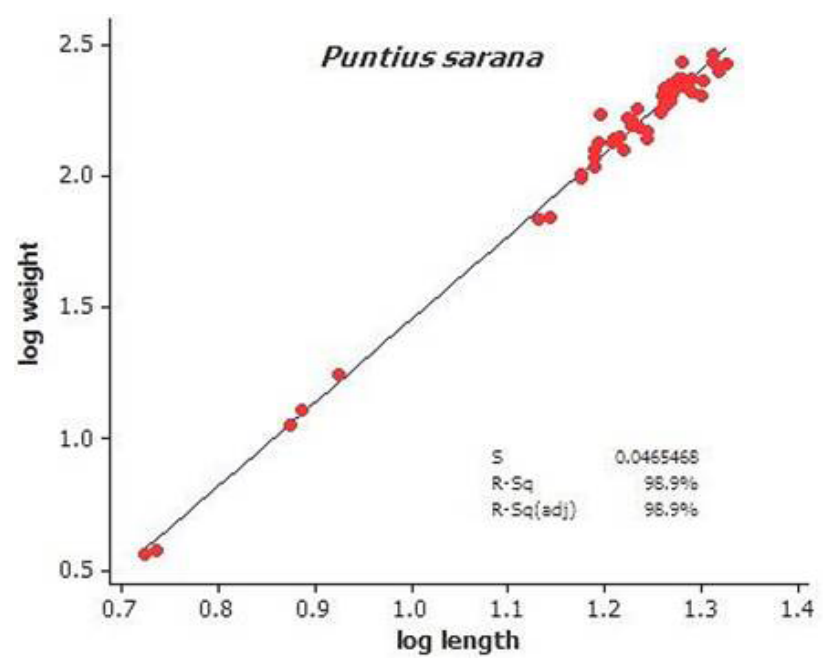

Fig. 10. Length-weight relationship of Puntius sarana (females).

There was a positive allometric growth of Puntius sarana females, observed in Vavuniya reservoir during the two-year study period. The regression analysis of LWR also revealed very strong coefficient of determination $r^{2}$ $=0.99$, where the ' $b$ ' value was 3.182 that significantly $(p=0.000)$ differed from the ideal isometric growth pattern (Fig. 10). These results suggested that $P$. sarana showed a non-isometric or positive allometric growth pattern. Hence this fish did not grow proportionately in Vavuniya reservoir. Sani et al. (2010) mentioned that in India (Betwa River) the positive allometric growth was observed in P. sarana, where ' $b$ ' $=3.18(\mathrm{n}=30)$. Carlander (1977) explained that the values of ' $b$ ' less than 2.5 (negative allometric) or greater than 3.5 (positive allometric) were often obtained from samples with narrow size ranges. But in Vavuniya reservoir the sample size was high $(\mathrm{n}=99)$ with broad total length sizes ranging from 7.2 to $26.5 \mathrm{~cm}$ (Table I). Findings of positive allometric growth pattern of $P$. sarana females was confirmed by statistical ( $p=0.000)$ significant test (Zar, 1996). When handling these specimens it clearly showed robust widening in the middle of the body. According to Pethiyagoda (1991) P. sarana is an omnivorous and littoral 
aufwuchs feeder that shows a wide range of feeding habits (aquatic insects, fish, some algae, prawns and ticks of cattle). Grazing cattle were also observed in the littoral zones of Vavuniya reservoir accounting for the ticks, which act as fish feeds. Hence, this may be the reason for its positive allometric growth patterns, when the environment is favourable with plenty of feeds. This could be supported by Sarkar et al. (2017), who stated that positive allometric growth in fish may be due to higher feeding.

In addition to the main findings, compared to all other species, death of Amblypharyngodon melettinus and Puntius sarana were observed in polluted locations of Vavuniya reservoir. Remarkably, these two indigenous species showed allometric growth pattern during the study period (Table I). The main cause of deaths may be attributed to the oil and grease contamination and lower dissolved oxygen content in the polluted locations. During wet season, automobile service stations strategically discharge their pollutants that is carried by rain water and sent via drainage to this reservoir. When these oil and grease pollutants enter this reservoir, they reduces the dissolved oxygen and increases toxicity. Chapman and Kimstach (1992) noted that dissolved oxygen (DO) concentrations below $5 \mathrm{mg} / \mathrm{L}$ adversely affect the functioning and survival of biological communities and below $2 \mathrm{mg} / \mathrm{L}$ may lead to the death of most fish. Hence, it could be suggested that $A$. melettinus and $P$. sarana were more vulnerable to pollution than other species in Vavuniya reservoir.

Further, Sani et al. (2010) stated that their objectives regarding fisheries management was evaluated by the LWR values of indigenous fish species in two habitats such as Gomti and Betwa rivers in India. Sivashanthini and Abeyrami (2003) also mentioned that the lengthweight relationship parameters were very much useful for cultivators and managers since they calculate the total weight or yield of the cultured fishes. Tesch (1971) and Wooten (1998) related the variations in the ' $b$ ' values with fish sample sizes examined, age/stanzas, sex, conditions, area or seasonal impacts and length classes of the fish caught. Stock assessment models and biomass estimations can be done by using LWR obtained from limited sample sizes of fish species (Binohlan and Pauly, 1998; Koutrakis and Tsikliras, 2003; Valle et al., 2003; Ecoutin et al., 2005; Özaydin and Taskavak, 2007; Simon and Mazlan 2008; Simon et al., 2009; Ndome et al., 2012). Hence, the LWR and growth pattern of fish species in Vavuniya reservoir will be of enormous benefit for its management and conservation.

\section{CONCLUSIONS}

Management strategies should be focused on the allometric growth performance of tropical inland fish to improve the isometric growth for successful thriving in the environment. Intensive fishing, irrational irrigation, and oil and grease contamination should be controlled to maintain the quantity as well as the quality of the aquatic medium to support the fish species. As the reservoirs are signals of climate change and responding biologically, based on the observed LWR and growth patterns may be used to forecast the effect of extreme hydro-climatic phenomena. Therefore, this study has revealed the baseline evidence on the LWR and the growth patterns of fish from Vavuniya Reservoir, Sri Lanka, which could be considered for studying the survival of local fish species to reach the optimal species richness, abundance and for future aquaculture practices.

\section{Statement of conflict of interest}

The authors declare no conflict of interest.

\section{REFERENCES}

Alam, M.M., Jahan, S.N., Hussain, M.A., Moumita, D., Goutham-Bharathi, M.P., Magalhães, A.L.B., Mazlan, A.G. and Simon, K.D., 2013. Lengthlength relationship, length-weight relationship and condition factor of freshwater fish species of Bangladesh. Aquacul. Aquar. Conserv. Legisl. Int. J. Bioflux Soc., 6: 498-509.

Ali, A., Dahanukar, N. and Raghavan, R., 2013. Lengthweight and length-length relationship of three species of snakehead fish. Channa diplogramma, C. marulius and C. striata from the riverine reaches of Lake Vembanad, Kerala, India. J. Threat. Taxa, 5: 4769-4773. https://doi.org/10.11609/JoTT. o3353.4769-73

Beyer, J.E., 1987. On length-weight relationships. Part I: Computing the mean weight of the fish of a given length class. Fish Byte, 5: 11-13.

Binohlan, C. and Pauly, D., 1998. The length-weight table. In: Concepts, design and data sources. ICLARM, Manila, Philippines, pp. 293.

Carlander, K.D., 1977. Handbook of freshwater fishery biology. The Iowa State University Press, Ames, IA, pp. 431.

Chapman, D. and Kimstach, V., 1992. The selection of water quality variable. In: Water quality assessments (ed. D. Chapman). Chapman and Hall Ltd., London, pp. 51-119. https://doi. org/10.4324/9780203476710

Das, P., Rahman, W., Talukdar, K. and Deka, P., 2015. Length-weight relationship and relative condition factor of Heteropneustes fossilis (Bloch) of Deepar 
Beel, a Ramsar site of Assam, India. Int. J. appl. Res., 1: 1024-1027.

De Silva, K.H.G.M., 1991. Growth rate and the role of Oreochromis mossambicus (Peters) in the fishery of a tropical, upland, deep, reservoir in Sri Lanka. Fish. Res., 12: 125-138. https://doi.org/10.1016/01657836(91)90037-G

Ecoutin, J.M., Albaret, J.J. and Trape, S., 2005. Length-weight relationships for fish populations of a relatively undisturbed tropical estuary: The Gambia. Fish. Res., 72: 347-351. https://doi. org/10.1016/j.fishres.2004.10.007

Froese, R., 2006. Cube law, condition factor and weightlength relationships: history, meta-analysis and recommendations. J. appl. Ichthyol., 22: 241-253. https://doi.org/10.1111/j.1439-0426.2006.00805.x

Froese, R., Tsikliras, A.C. and Stergiou, K.I., 2011. Editorial note on weight-length relations of fishes. Acta Ichthyol.. Piscat., 41: 261-263. https://doi. org/10.3750/AIP2011.41.4.01

Froese, R. and Pauly, D., 2018. Fish base. World Wide Web Electronic Publication.

Goonatilake, S.A., 2012. The taxonomy and conservation status of the freshwater fishes in Sri Lanka. The national red list 2012 of Sri Lanka: Conservation status of the fauna and flora. Ministry of Environment, Colombo, Sri Lanka, pp. 77-87.

Hile, R., 1936. Age and growth of the cisco Leucichthy sartedi (Le Sueur) in the lakes of the north-eastern highlands. Bull. U.S. Bur. Fish., 48: 211-317.

Hossain, M.Y., Ahmed, Z.F., Leunda, P.M., Jasmine, S., Oscoz, J., Miranda, R. and Ohtomi, J., 2006. Condition, length-weight and length-length relationships of the Asian srtiped catfish Mystus vittatus (Bloch, 1794) (Siluriformes: Bagridae) in the Mathabhanga River, southwestern Bangladesh. J. appl. Ichthyol., 22: 304-307. https://doi. org/10.1111/j.1439-0426.2006.00803.x

Islam, M.R. and Mollah, M.F.A., 2013. Morphological observation and pg-induced breeding of Glossogobius giuris. J. Sci. Technol., 11: 171-180.

Javaid, M.Y., 1971. Diurnal periodicity in the feeding study of some freshwater fishes of West Pakistan. The Nucleus, 8: 131-144.

Jayaprakah, A., 2001. Length weight relationship and relative condition in Cynoglossu macrostomus Norman and $C$. arel (Schneider). J. mar. biol. Assoc. India, 43: 148-154.

Joadder, A.R., 2009. Length-weight relationship and condition factor (Kn) of Gobi, Glossogobius giuris (Hamilton) from "Atrai River" in the Northern part of Bangladesh. J. Fish. Int., 4: 1-4.
Kilambi, R.V., 1986. Age, growth and reproductive strategy of the snakehead, Ophiocephalus striata Bloch, from Sri Lanka. J. Fish Biol., 29: 1322. https://doi.org/10.1111/j.1095-8649.1986. tb04922.x

Koutrakis, E.T. and Tsikliras, A.C., 2003. Lengthweight relationships of fishes from three northern Aegean estuarine systems (Greece). J. appl. Ichthyol., 19: 258-260. https://doi.org/10.1046/ j.1439-0426.2003.00456.x

Le Cren, E.D., 1951. The length-weight relationships and seasonal cycle in gonad weight and condition in the perch (Perca fluviatilis). J. Anim. Ecol., 20: 201-219. https://doi.org/10.2307/1540

Martin, W.R., 1949. The mechanics of environmental control of body form in fishes. Univ. Toronto Stud. Biol., 58: 1-91.

Muhammad, H., Iqbal, Z., Bashir, Q. and Hanif, M.A., 2017. Length-weight relationship and condition factor of catfish species from Indus River, Pakistan. Punjab Univ. J. Zool., 32: 35-38.

Munro, I.S.R., 1955. The marine and freshwater fishes of Ceylon. Department of External Affairs, Canberra, Australia.

Narejo, N.T., Jalbani, S., Khan, P. and Memon, F., 2016. Food and feeding habits of sting catfish, Heteropneustes fossilis (Bloch) from Manchar Lake District Jamshoro Sindh Pakistan. Sindh Univ. Res. J. (Sci. Ser.), 48: 473-476.

Ndome, C.B. and Eteng, A.O., 2012. Length-weight relationship and condition factor of the smooth mouth marine catfish (Carlarius heudelotii) in the gulf of Guinea, Niger delta, Nigeria. AACL Bioflux, 5: 163-167.

Özaydin, O. and Taskavak, E., 2007. Length-weight relationships for 47 fish species from Izmir Bay (eastern Agean Sea, Turkey). Acta Adriat., 47: 211216.

Pathak, S.C., 1975. Length-weight relationship, condition factor and food study of Labeo calbasu (Ham.) from the reservoir (M.P.). J. Inland Fish Soc. India, 7: 58-64.

Patrick, A.E.S., Kuganathan, S. and Edirisinghe, U., 2017. Species composition and abundance of fishes with seasonal fluctuations of rainfall and water level in Vavuniya reservoir, Sri Lanka. Int. Res. J. environ. Sci., 6: 12-21. http:/www.isca.in/IJENS/ Archive/v6/i6/3.ISCA-IRJEvS-2017-048.php

Pethiyagoda, R., 1991. Freshwater fishes of Sri Lanka. Wildlife Heritage Trust, Colombo. https://doi. org/10.2307/1446131

Ricker, W.E., 1973. Linear regressions in fishery 
research. Fish. Res. Bd. Can., 30: 409-434. https:// doi.org/10.1139/f73-072

Sarkar, M., Das, S.K., Mondal, A. and Bhakta, D., 2017. Length-weight relationship and relative condition factor of carps Labeo bata and Labeo rohita from Kulia beel (Wetland) of Nadia district of West Bengal. J. Ent. Zool. Stud., 5: 1033-1036.

Sani, R., Gupta, B.K., Sarkar, U.K., Pandey, A., Dubey, V.K. and Lakra, W.S., 2010. Length-weight relationships of 14 Indian freshwater fish species from the Betwa (Yamuna River tributary) and Gomti (Ganga River tributary) rivers. J. appl. Ichthyol., 26: 456-459. https://doi.org/10.1111/ j.1439-0426.2009.01388.x

Schiemer, F., 1996. Significance of filter-feeding fish in tropical fresh waters. In: Perspectives in tropical limnology (eds. F. Schiemer and K. Boland). SPB Academic, Amsterdam, pp. 65-76.

Silva, E.I.L., Simon, D. and Schiemer, F., 2008. Catchment characteristics, hydrology, limnology and socio-economic features of three reservoirs in Sri Lanka, In: Aquatic ecosystems and development: Comparative Asian perspectives (eds. F. Schiemer, D. Simon, U. Amarasinghe and J. Moreau). Backhuys Publishers, Kerkwerve, The Netherlands, pp. 19-44.

Simon, K.D. and Mazlan, A.G., 2008. Length-weight and length-length relationships of archer and puffer fish species. Open Fish Sci. J., 1: 19-22. https://doi. org/10.2174/1874401X00801010019

Simon, K.D., Bakar, Y., Samat, A., Zaidi, C.C., Aziz, A. and Mazlan, A.G., 2009. Population growth, trophic level, and reproductive biology of two congeneric archer fishes (Toxotes chatareus, Hamilton 1822 and Toxotes jaculatrix, Pallas 1767) inhabiting Malaysian coastal waters. J. Zhejiang Univ. Sci. $B$ (Biomed. Biotechnol.), 10: 902-911. https://doi. org/10.1631/jzus.B0920173
Sivashanthini, K. and Abeyrami, B., 2003. Lengthweight relationship and condition factor of Gerres oblongus (Pisces: Perciformes) from the Jaffna lagoon, Sri Lanka. Indian J. mar. Sci., 32: 252-254.

Smith, M.A., 1991. Models of seasonal growth of the equatorial carp Labeo dussumieri in response to the river flood cycle. Environ. Biol. Fish., 31: 157-170. https://doi.org/10.1007/BF00001017

Snedecor, G.W., 1963. The comparison of two groups. In: Statistical method, Chapter 4. The IOWA State College Press, Ames, IOWA, USA, pp. 534.

Sunil, M.S., 2000. Length-weight relationship in Rasbora daniconius (Ham.) from Achancoil River, Pathanamthitta, Kerala, India. Indian J. Fish., 47: 271-274.

Tesch, F.W., 1971. Age and growth. In: Methods for assessment of fish production in fresh waters (ed. W.E. Ricker). Blackwell Scientific Publications, Oxford, pp. 98-130.

Thirunavukkarasu, P., Jayalakshmibalaji, S., Elumalai, V. and Subbulakshmi, G., 2012. Length-weight relationship of freshwater fish Puntius chola and Puntius dorsalis from Cholavaram Lake. Int. J. Curr. Res., 4: 134-135.

Valle, C., Bayle, J.T. and Ramos, A.A., 2003. Weightlength relationships for selected fish species of the western Mediterranean Sea. J. appl. Ichthyol., 19: 261-262. https://doi.org/10.1046/j.14390426.2003.00492.x

Wooten, R.J., 1998. Ecology of teleost fishes. Kluwer Academic Publishers, Dordrecht, The Netherlands.

Zar, J.H., 1996. Biostatistical analysis, $3^{\text {rd }}$ edn. PrenticeHall, USA, ISBN: 0-13-084542-6, pp. 662.

Zaret, T.M., 1980. Life history and growth relationships of Cichla ocellaris, a predatory South American cichlid. Biotropica, 12: 144-157. https://doi. org/10.2307/2387730 